\title{
Comprehensive Measurement and Evaluation System of High-speed Motorized Spindle
}

\author{
Da-Shuai $\mathrm{ZHOU}^{1) 2}$ and \\ Liang-sheng $W^{2)}$ \\ 1) College of Mechanical Engineering \& \\ Applied Electronic Technology; Beijing \\ University of Technology; Beijing 100124; \\ China \\ 2) College of Mechanical Engineering \\ Technology; Jiamusi University, \\ Jiamusi 154007, China
}

xiaogengniu@gmail.com

\author{
Keywords \\ Comprehensive Properties \\ High-speed Motorized Spindle \\ Evaluation System

\section{Ključne riječi \\ Evaluacijski sustav \\ Sveobuhvatna svojstva \\ Visokobrzinsko pogonsko vreteno}

Received (primljeno): 2010-03-08

Accepted (prihvaćeno): 2010-08-31
Original scientific paper

Reducing the manufacturing time is the trend of high precision manufacturing, and the precision of a work-piece is very important for the manufacturing industry. The high-speed motorized spindle is the most critical part and becoming more widely used in the machine tool at present, and its precision may affect the overall performance of high-speed cutting. Most of the studies on high-speed cutting are focused on the cutting force, the vibration of the spindle and effects of the spindle's thermal deformations; hence, how to roundly measure and objectively evaluate a high-speed spindle is an inevitable question. Because the comprehensive dynamic properties and evaluation system of spindles directly affect the cutting ability of the whole machine tool before they are manufactured. This paper presents a comprehensive measurement and evaluation system of a high-speed motorized spindle, which reflect the overall performance of motorized spindle and bases on an international standard

\section{Sveobuhvatno mjerenje i evaluacija sustava visokobrzinskog pogonskog vretena}

Izvornoznanstveni članak

Smanjenje proizvodnog vremena tendencija je u visoko preciznoj proizvodnji, pri čemu je preciznost radnog komada vrlo važna u proizvodnoj industriji. Pri tome je visokobrzinsko pogonsko vreteno jedan od najkritičnijih dijelova koji se naširoko koristi u alatnim strojevima, pa njegova preciznost predstavlja važnog čimbenika u sveukupnoj izvedbi visokobrzinskog rezanja. Mnoge studije o visokobrzinskom rezanju su fokusirane na sile rezanja, vibraciju vretena kao i na efekte toplinske deformacije vretena; stoga, kako propisno mjeriti i objektivno evaluirati visokobrzinsko vreteno jedno je od neizbježnih pitanja. Jer sveobuhvatna dinamička svojstva i evaluacija sustava vretena izravno utječu na rezna svojstva cjelokupnog alatnog stroja, prije no što je proizveden. Ovaj rad prikazuje sveobuhvatno mjerenje i evaluaciju visokobrzinskog pogonskog vretena, koja se odražavaju na sveukupne odlike pogonskog vretena, a koja se bazirana na međunarodnim standardima.

\section{Introduction}

A typical high-speed motorized spindle system for machine tools is shown in Figure 1. It consists of the tool, tool holder, spindle shaft, bearings, pulley, clamping unit, and the housing attached to the machine tool. All the above units are directly driven by brushless motors and the spindle shaft is supported by angular contact bearings. For a very high-speed spindle, as illustrated in Figure 2, the motor is usually seated inside the spindle housing for better balance [1-2] .

A high-speed motorized spindle is one of the most important techniques of the super precise machine tool. Elevated temperature, speed control loading characteristics, precision maintenance, vibration intensity, and rotation error are not only the key demand of motorized spindle's capability but also an important

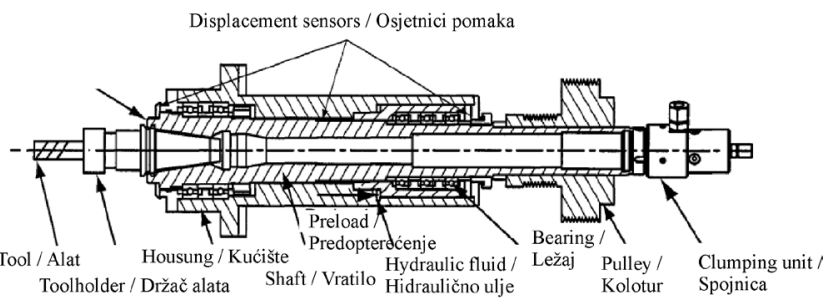

Figure 1. A spindle system

Slika 1. Sustav vretena

index to evaluate its performance. At the same time, how to measure and evaluate its performance has become one of the key tasks which affect the development of comprehensive testing system for the motorized spindle. Fortunately, extensive research has been conducted as follows. 


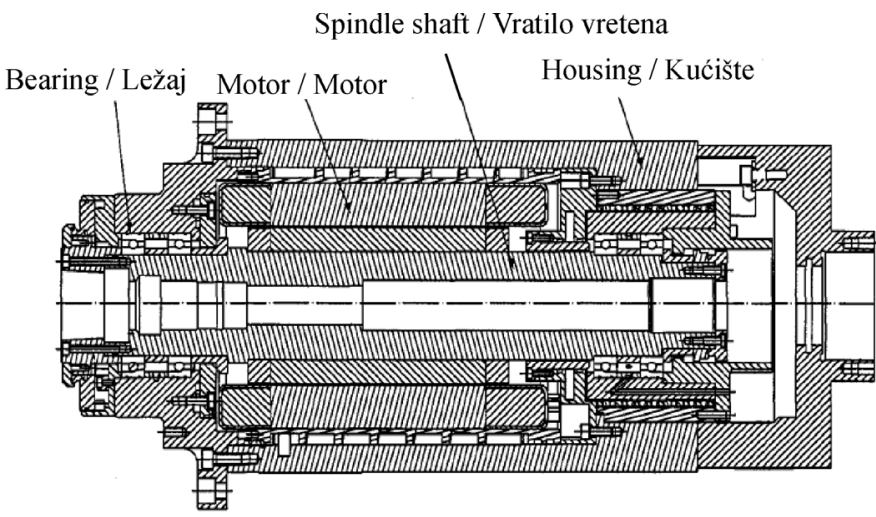

Figure 2. A high-speed motorized spindle

Slika 2. Visoko brzinsko pogonsko vreteno

Machine tools of cutting speeds did not exist commercially until the late 1980s [3-4] though theories of high-speed metal cutting were reported in the 1930s [5].In 1959 Tlusty put forward a systematized method of test machine tools [6]. As a result, a variety of terms came into use throughout the world to describe and explain the various phenomena found during testing and subsequent use of the machine tool spindle. In 1967, Bryan [7] presented a new viewpoint in defining the entire subject of rotational axes. In 1972, Goddard and Burdekin [8] built a spindle measurement system which could measure spindle accuracy. After this, many machine tool testing methods were adopted in many international standards such as ASME, ANSI and ISO [9-11], especially drew up the standard for the test of the spindle. In the past, little research has been conducted in to a comprehensive measurement and evaluation system for high-speed motorized spindle, and early spindle measurement focused mainly on static and quasi-static analysis. Moreover, spindle error measurement and thermal characteristics research can be only found as two fields have concentrated on the methods of a high-accuracy rotation axes at the low rotational speed. of course, It is well known that the relevant studies on the high-speed motorized spindle have a very extensive scope; it is a mechanical-electricalhydraulic integration system engineering, ranging from mechanics and electromagnetics, thermokinetics and electromechanical coupling, the concomitant substance including: the modeling of machine tool system simulation consisting of a rotating shaft, tool holder, angular contact ball bearing, thermal drift, thermal error, thermal deformation cause reduced stiffness, housing, machine tool mounting, and the high-speed motorized spindle structure design and analysis to a study of the radiation of the high-speed spindle, the influences of various bearings on the high-speed spindle to high-speed spindle materials and their applications, et al. Studies on the comprehensive measurement system for high-speed motorized spindle include: In 2003, Cheng-Hsien Wu and Yu-Tai Kung [12] presented a parametric study on oil/air lubrication of a high-speed spindle and found that the performance of a high-speed spindle under different lubrication parameters and preloads along with their results provided a useful tool in designing a high-speed spindle with a small increase in temperature and sufficient static stiffness. In 2005, Wen-Yu Jywe [13] et al. studied the development of a high-speed measuremen system using a laser diod and a quadrants seneor; this system does not need any reference, it is easy to set up and can be applied to measure the spindle errors, the spindle speed and the spindle indexing. In 2007, Chi-Wei Lin [14] et al,offered the model-based design of motorized spindle systems to improve dynamic performance at high speeds; their paper first develops a design flow chart to represent the overall spindle design problems. Based on this flow chart, eight design parameters are identified, a design sensitivity analysis of these eight design parameters is then conducted based on an integrated finite element method model to investigate their influence on the natural frequencies of the spindle system.

This paper is based on the above background, proposes a comprehensive measurement and evaluation system for high-speed motorized spindle, which comprises four aspects on measurement and evaluation of highspeed motorized spindle that basically includes all the behaviours. The real contents including: 1. spindle's temperature rise and thermal deformation test. 2 . speedload characteristic measurement of high-speed motorized spindle 3. the measurement of motorized spindle's rotating accuracy 4. The measurement of motorized spindle's rotating accuracy, and so on.

\section{The overall composition of measurement and evaluation system for high-speed motorized spindle}

From the spindle of the working principle and structure we know that the measurement and evaluation system is a composite system involving a motorized spindle itself and its enclosure, along with its variable-frequency system and refrigeration system. Moreover, this system consists of hardware and software platform. Hardware platform includes measure device, sensors and its bracket, vibration exciter and its bracket for the installation of testing equipment and loading equipment (such as electric eddy current dynamometer, or a magnetic powder brake), retarder, etc, as shown in Figure 3. The software design consists of the measurement data processing, analysis, storage, and graphics and so on; the specific test content is based on the corresponding test items, the choice of equipment and test purpose, but should be operable with high reliability, easy maintenance features. 
Elecrtic eddy current dynamometer / Moterized spindle /

Električni vrtložnostrujni dinamometar Pogonsko vreteno

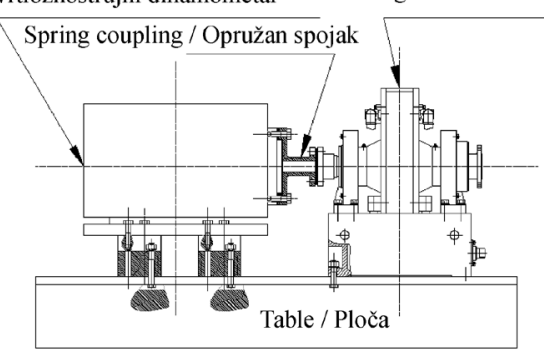

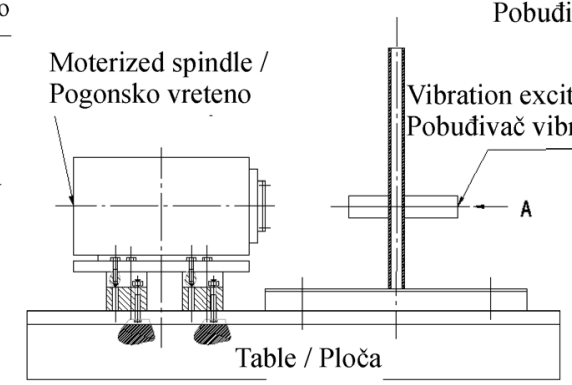

Vibration exciter and its bracket / Pobuđivač vibracija i njegova konzola

Figure 3. Motorized spindle measurement platform structure

Slika 3. Strukturna platforma mjerenja pogonskog vretena

\section{The specific content of measurement and evaluation system}

\subsection{Spindle's temperature rise and thermal deformation test}

Spindles' thermal properties, besides the accuracy of rotation and static and dynamic stiffness, strongly afect the accuracy of a machine tool. The thermal errors generally come from the thermal deformations of the machine elements caused by heat sources which exist within the structure, i.e. ball screws, bearings, nuts, axis drive motors, friction on the surfaces, cutting processes, the flow of coolant/lubricating oil, and the ambient temperature. Those thermal errors have been reported to be about $70 \%$ of the total positioning error of the machine tool. This paper uses a spindle measurement system supplied by AUTOMATED PRECISION, INC (API). There are 6 degrees of freedom (6 DOF) components in the spindle error motion in machine tools in this system, i.e. two radial error motions, one axial motion, two tilting motions, and one indexing error motion (air temperature sensor ). From the point of view of machine tool accuracy, the indexing error motion of the spindle can be ignored and thus only 5 DOF spindle thermal errors are considered in this paper. Figure 4 shows the measurement device for the 5 DOF spindle errors (i.e., pitch, yaw, X-, $\mathrm{Y}$-, and Z-axes) by measuring the displacement of the mandrel over a warm up or cool down cycle, in which the jig for the standard pole and 5 gap sensors are arranged around the spindle and interfaced to a PC. Temperature variations are measured with the thermo-couples around the machine tool structure.

\section{The measurement procedure:}

To set up this system; first place the test artifact in the machine spindle, fix the gage holder and indicators to the work-piece table aligned to the axes, and then place the air temperature sensor near the center of the machine work volume, and place the surface temperature sensor

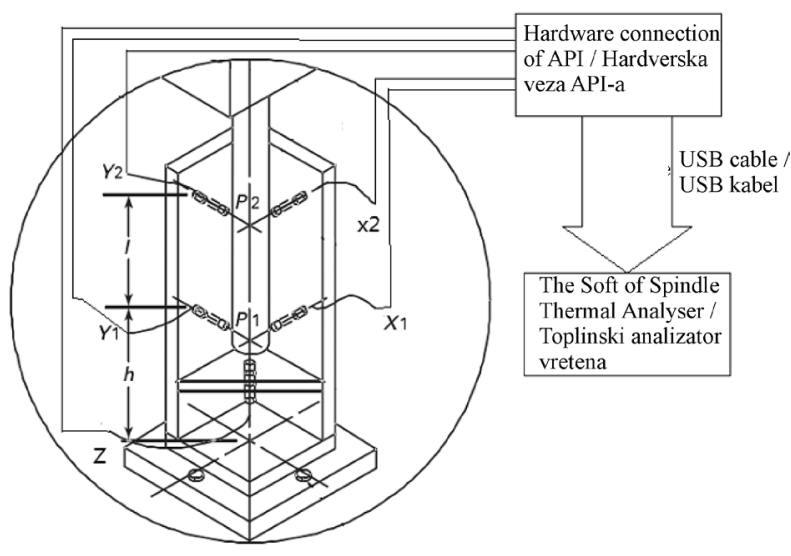

Figure 4. Typical device for temperature variation error measurement on a vertical machining center

Slika 4. Tipična jedinica za mjerenje pogreške temperaturne promjene u vertikalnom središtu stroja

on the spindle nose. Next, adjust the machine axes and indicators so that all indicators are near the centers of their ranges, as shown in Figure 5. After checking for setup hysteresis in each direction sensor, ensure that electronic test equipment, computers, etc., do not touch the machine. These shall be located as far as possible from the machine tool for the duration of the test. And place the machine in the "feed-hold" condition and zero indicators electronically (if applicable).After all, systems that normally operate while the machine is idle(including systems to control effects of environmental temperature) shall be operating; then record data from the five displacement indicators and two temperature sensors at intervals of $60 \mathrm{sec}$ or less, at the same time displacement Sensor and the external temperature sensor readings are displayed together. The test period should be at least 4 $\mathrm{hr}$. However, the minimum recommended test time is 24 $\mathrm{hr}$, and normal activities surrounding the machine shall continue during the test. 


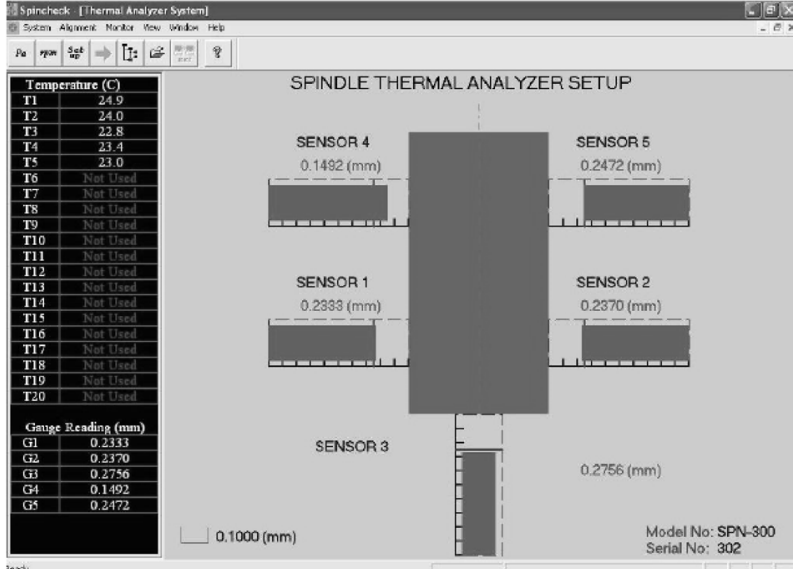

Figure 5. Spindle thermal analyzer setup screen

Slika 5. Ekransko sučelje toplinskog analizatora vretena

Result of thermal drift for each direction and angular thermal drift about the $\mathrm{X}$ direction and $\mathrm{Y}$ direction may be taken directly from a graph of the results such as that shown in Figure 6.
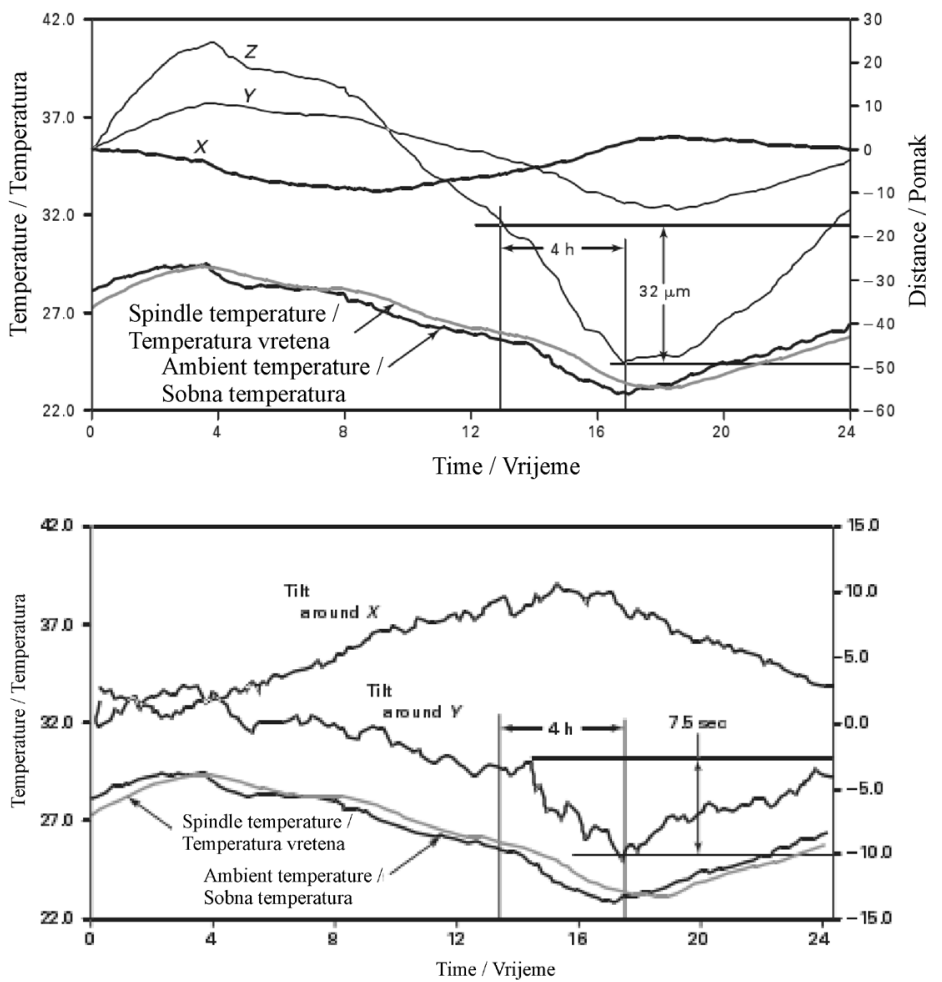

Figure 6. A typical test result of temperature,displacement, and tilt motion

Slika 6. Tipičan test rezultata temperature, pomaka i nagibnog gobanja

\subsection{Speed-load characteristic measurement of high- speed motorized spindle}

A motorized spindle is a non-shell special motor, so it also has speed-load characteristics of a motor, and the test characteristics of its work will be completed through the spindle speed-load characteristic tests. By loading devices such as electric eddy current dynamometer, magnetic powder brake and torquemeter et al, load $0.25 \sim 1.25$ times the power rating of the motorized spindle and measure the relevant parameters of motorized spindle. The aim to measure speed-load characteristic is not only to obtain the main technical performance (such as speed, torque, output power, etc.) in the case of a nominal operation whether it meets the technical standards stipulated in the requirements of the guaranteed value, but also to understand the main technical properties of a motorized spindle with load changing circumstances which manufacturers or users want to get as a basis for a reasonable actual selection of a spindle.

The measurement procedure: First, bind motorized spindle to electric eddy current dynamometer with spring coupling and fix them on the table, as illustrated in Figure 7, then start the spindle, and select a certain speed between the lowest to the highest speed (take respectively no less than 4 speeds in the range of speed control with constant torque and constant power speed regulation), use various speed under the electric eddy current dynamometer load slow to the motorized spindle from the low power to the maximum power to measure at this time corresponding to the torque, power and speed, finally drawing a speed-load characteristic curve, as shown in Figure 8.

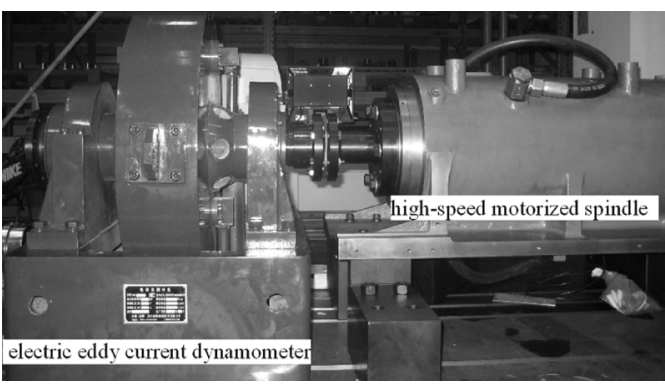

Figure 7. The dynamometer test site

Slika 7. Položaj ispitnog dinamometra

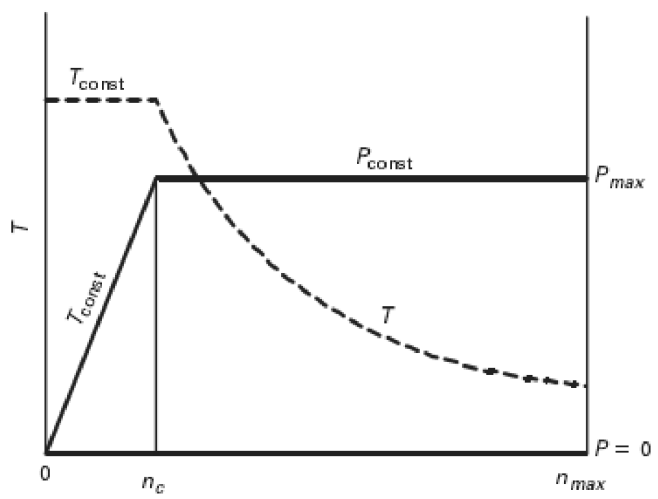

Figure 8. Motorized spindle speed load caracteristic curve

Slika 8. Karakteristična krivulja brzine opterećenja pogonskog vretena 


\subsection{The measurement of a motorized spindle's rotating accuracy}

Motorized spindle rotating accuracy is the key norm to evaluate the performance and quality for machine tool and set of shaft machinery, and the main factor to affect the precision machining and accuracy.

In the traditional processing methods, rotating accuracy is one of the important factors to affect the precision of $\mathrm{CNC}$ machining, it directly affects the shape precision processing parts, surface quality and roughness. Production practice results showed that about $30 \% \sim 70 \%$ of roundness error after accurate lathe cause by the rotating spindle and the higher precision of machine tools, the greater the proportion. With the new development of accuracy to machinery manufacturing, the corresponding detection accuracy is also moving to a more high-precision, as mentioned in thermal deformation test; this project test also use the dynamic measurement system of spindle produced by API. This System is an advanced and accurate measuring instrument for determining the spindle rotation error of a machine such as an asynchronous and average radial error motion, it comprises three API capacitance sensors which are arranged orthogonally on a base and aligned with a precision sphere as illustration Figure 9. There is an index sensor attached to the fixture which will produce a pulse every time the machine rotates one revolution. The index signal will be used to synchronize the data sampling rate with the machine rotating speed. All fixtures and gauges are built for rugged use in a machine shop and production environment during the testing. Because of the exceptionally high performance of the API gauges, the Analyzer can allow as fast as $60,000 \mathrm{rpm}$ spindle speed of operation; at the same time, the system comes complete with interactive software and step-by step procedures that make it easy to perform a system setup and data analysis.

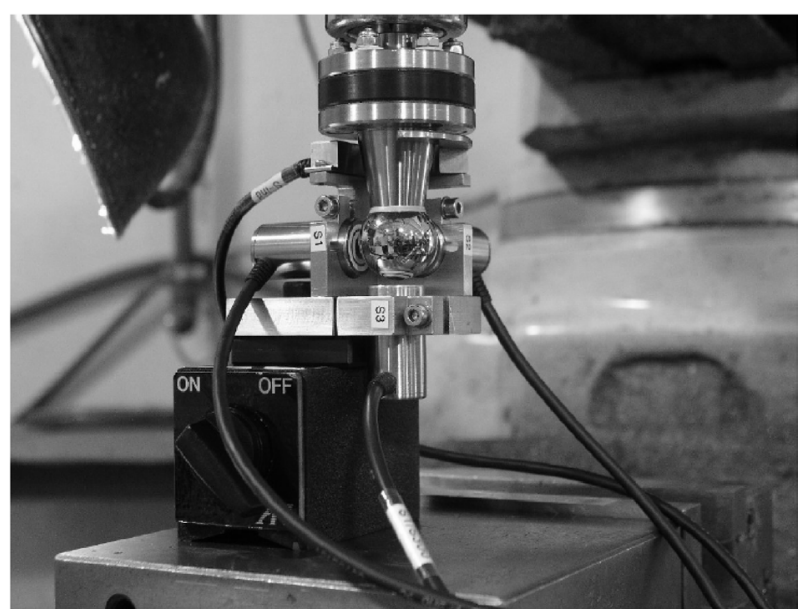

Figure 9. The test device for spindle's rotating accuracy

Slika 9. Ispitna jedinica točnosti rotacije vretena
The measurement procedure: First install the software for the spindle measurement system on the PC computer, next position the capacitance sensors into the mount relative to the spindle by providing a real-time view of the sensor location, and then connect the capacitance sensors and related equipment to the PC computer through the USB cable, finally turn on the computer power and start the spindle measurement software to do the measurement on a machine. The spindle measurement system setup, real time data acquisition and data analysis result are shown in Figure 10.

a)

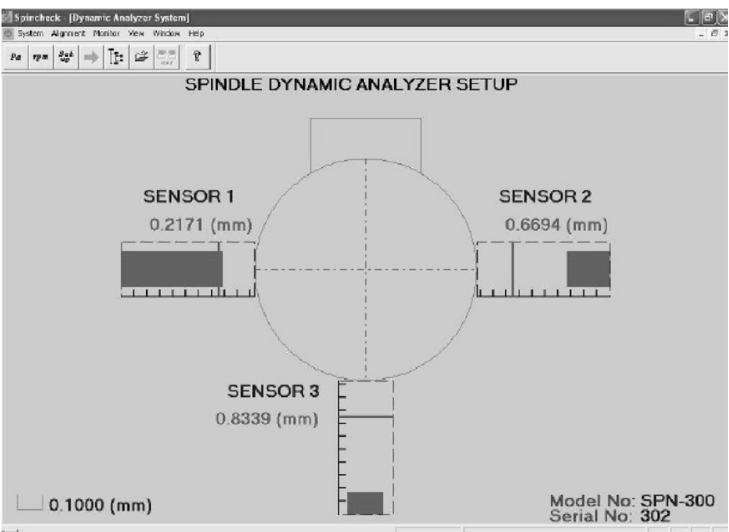

b)

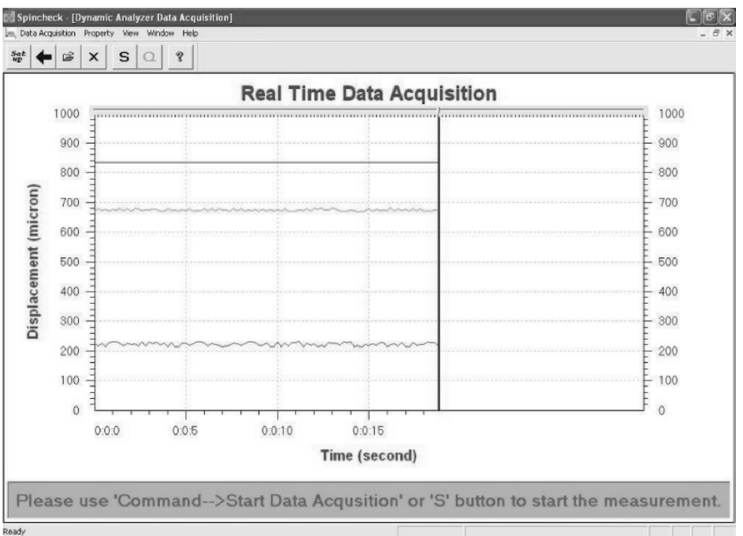

Average error motion value

Srednja vrijednost poćreške gibanja

c)

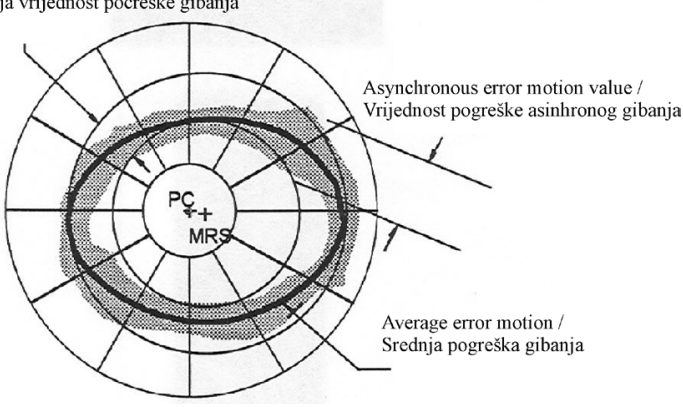

Figure 10. a) the spindle measurement system setup, b) real time data acquisition and c)data analysis result

Slika 10. a) Postava sustava mjerenja vretena, b) akvizicija podataka u realnom vremenu i c) rezultati analize podataka 


\subsection{Dynamic and static characteristics measurement of high-speed motorized spindle}

The machine tools must have higher rigidity, stability, and reliability. Among all the components of a machine tool, the motorized spindle is the most critical part, since its dynamic and static properties directly affect the cutting ability of the whole machine tool. Whether spindle's dynamic and static characteristics are good or not mainly depend on its ability to resist forced vibration and selfexcited vibration, that is, the spindle's dynamic and static characteristics. Static stiffness of motorized spindle, or the stiffness $K$, is reflected in the capacity of the spindle to resist external load and usually is defined statically as a ratio of the applied force to the displacement of a machine element. Its mathematical expression is as follows:

$K=\frac{F}{y}(N / \mu m)$

Where $K$ is expressed in $N / \mu \cdot m, F=$ force, $\mathrm{N} ; y=$ displacement, $\mu \cdot m$.

Based on the experimental and theoretical results, we conclude that: the dynamics characteristic of spindlebearing system has, to a great extent, influenced the quality and ability of machine tools, in addition, it has connection with the size of preload of the front bearing. Therefore, the dynamics test includes the following: axial stiffness and radial stiffness of the front bearing of motorized spindle. The measurement procedure:

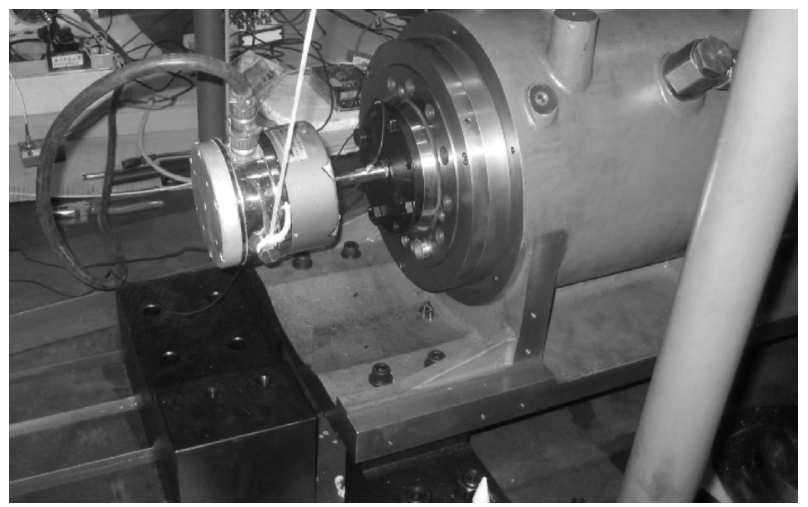

Figure 11. Measurement of axial stiffness

Slika 11. Mjerenje aksijalne krutosti

First position the motorized spindle on the table machine in the stationary state and mount the measuring instrument in the manner used for the performance test, then carry out excitation and pick-up in the front spindle for axial and radial respectively, identify the natural frequency and damping ratio from the measured frequency response function, and recognize the stiffness from the measured dynamic flexibility curve, Figure 11 and Figure 12 shows instrumentation of axial stiffness and radial stiffness separately.

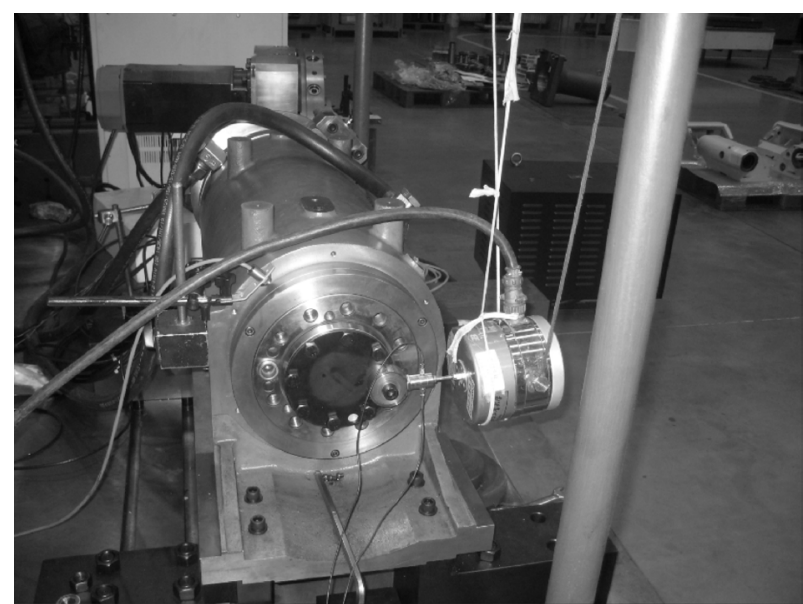

Figure 12. Measurement of radial stiffness

Slika 12. Mjerenje radijalne krutosti

The experimentally verified mathematical model predicts that the preload can increase the bearing stiffness, leading to increased natural frequencies, which shifts the stability lobes to the right towards higher speeds. However, a higher preload reduces the damping, which decreases the dynamic stiffness at the tool tip hence reducing the chatter free, depth of cuts. The preload cannot efficiently improve the stability lobes, but it can enhance the static stiffness and reduce the forced vibrations.

\section{Summary}

This paper represents a new comprehensive measurement and evaluation system of high-speed motorized spindle, and confirms the usefulness of the motorized spindle developed for industrial use. This system, by its modularity, is easily adaptable to other types of spindles and makes it possible to qualify a spindle for a given machining process. It can also provide a guideline for machine tool designers to estimate correct system dynamics for different operating conditions. Moreover, it is easy to set up at low cost. Its characteristics are shown below:

1. This measurement and evaluation system has a small size, full-featured, high precision, strong operability features, basically meeting its requirements.

2. This measurement and evaluation system can be widely applied to a motorized spindle, internal combustion engine and other rotating machinery vibration test and analysis.

3. The set of measurement and evaluation system uses a number of internationally accepted standards and methods such as ANSI and ISO so that it provides a guarantee for the test method and basis.

4. This software for measurement and evaluation system is a windows-based software, can realize 
time domain, frequency domain also showed, various data processing and convenient features, and obtain semi-automatic measurement under the software's guidance.

However, this measurement and evaluation system involves more items, the measurement process is more complicated; what's more, some items lack reference to quantitative criteria. Refining classification of types of machine and dimension series, is recommendes alowe with in creasing test samples in order to obtain enough statistical data as a basis for comprehensive measurement and evaluation system of high-speed motorized spindle.

\section{REFERENCES:}

[1] CHANG, C.; CHEN, J.; CHEN, T.: A theory thermal growth control techniques of high speed spindles [C]. Valencia, Spain: Inst. of Elec. and Elec. Eng. Computer Society, 2008.

[2] YUZHONG CAO, Y. A.: Modling of SpindleBearing and Machine Tool System for Virtual Simulation of Milling Operations [J]. International Journal of Machine Tools \& Manufacture. 2007, 47: 1342-1350.

[3] R. K.; MCGEE, J.; THOMPSON, R. A. et al.: $A$ methodology for establishing the machine tool system requirements for high-speed/high-through put machining $[J]$. trans. of ASME,journal of Engg. for industry. 1985, 107(316-324).

[4] KAUFELD, M.: High-speed milling from a user's and machine builder's viewpoint [J]. werkstattand betrieb. 1990, 123(10): 797-801.

[5] SALOMON, C.: Verfhren zur bearingbeitung von metallen oder bei bearbeitung durch schneidencede werkzeuge von sich ahnlich verhaltenden werkstoffen, Deutsches patent number 523594.
[6] TLUSTY, J.: System and method of testing machine tools [J]. Microtecnic 13. 1959: 162-178.

[7] BRYAN, J.; CLOUSER, R. W.; HOLLAND, E.: Spindle accuracy [J]. American Machinist. 1967(4): 149-164.

[8] GODDARD, C.; BURDEKIN: A measuring system for the evolution of spindle rotation accuracy [Z]. Birmingham: 1972.

[9] ANSI/ ASME Standard B5.54. Method For Performance Evaluationpf CNC Machining Center. 1992: 149-164.

[10] ANSI/ ASME Standard B5.57. Method For Performance Evaluationp of CNC Turning Center. 1998: 149-164.

[11] ISO230 Part3[M]. Test conditions for metal cutting machine tools, Evaluation of Thermal Effects, 2001: 149-164.

[12] WU, C.; KUNG, Y.: A parametric study on oil/air lubrication of a high-speed spindle [J]. Precision Engineering. 2003, 29(2): 162-167.

[13] JYWE, W.; CHEN, C.: The development of a higespeed spindle measurement system using a laser diode and a quadrants sensor [J]. international journal of machine tools and manufacture. 2005(45): 1162-1170.

[14] LIN, C.; TU, J. F.: Model-baded degign of motorized spindle system go improve dynamic performance at high speeds [J]. Journal of manufactureing processes. 2007, 9(2): 94-108. 